\title{
Altered coronary microvascular serotonin receptor expression after coronary artery bypass grafting with cardiopulmonary bypass
}

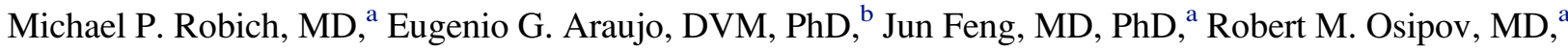 \\ Richard T. Clements, PhD, ${ }^{\mathrm{a}}$ Cesario Bianchi, MD, PhD, ${ }^{\mathrm{a}}$ and Frank W. Sellke, $\mathrm{MD}^{\mathrm{a}, \mathrm{c}}$
}

Objective: We evaluated roles of serotonin $1 \mathrm{~B}$ and $2 \mathrm{~A}$ receptors, thromboxane synthase and receptor, and phospholipases $\mathrm{A}_{2}$ and $\mathrm{C}$ in response to cardiopulmonary bypass.

\begin{abstract}
Methods: Patients' atrial tissues were harvested before and after cardiopulmonary bypass with cardioplegia $(\mathrm{n}=$ 13). Coronary microvessels were assessed for vasoactive response to serotonin with and without inhibitors of serotonin $1 \mathrm{~B}$ and $2 \mathrm{~A}$ receptors and phospholipases $\mathrm{A}_{2}$ and $\mathrm{C}$. Expressions of serotonin receptor messenger RNA were determined with reverse transcriptase polymerase chain reaction. Expressions of serotonin receptors and thromboxane $\mathrm{A}_{2}$ receptor and synthase proteins were determined with immunoblotting and immunohistochemistry.
\end{abstract}

\begin{abstract}
Results: Microvessel exposure to serotonin elicited 7.3\% $\pm 2 \%$ relaxation before bypass, changing to contraction of $-19.2 \% \pm 2 \%$ after bypass $(P<.001)$. Additions of specific serotonin $1 \mathrm{~B}$ receptor antagonist and inhibitor of phospholipase $\mathrm{A}_{2}$ resulted in significantly decreased contraction, $-8.6 \% \pm 1 \%(P<.001)$ and $2.8 \% \pm 3 \%$ $(P=.001)$, respectively. Serotonin 1B receptor messenger RNA expression increased $1.82 \pm 0.34$-fold after bypass $(p=.044)$; serotonin 2A receptor messenger RNA expression did not change. Serotonin 1B but not $2 \mathrm{~A}$ receptor protein expression increased after bypass by $1.35 \pm 0.7$-fold $(P=.0413)$. Thromboxane synthase and receptor expressions were unchanged after bypass. Serotonin 1B receptor increased mainly in arterial smooth muscle. There were no appreciable differences in arterial expressions of thromboxane synthase or receptor.
\end{abstract}

Conclusions: Serotonin-induced vascular dysfunction after cardiopulmonary bypass with cardioplegic arrest may be mediated by increased expression of serotonin $1 \mathrm{~B}$ receptor and subsequent phospholipase $\mathrm{A}_{2}$ activation in myocardial coronary smooth muscle. (J Thorac Cardiovasc Surg 2010;139:1033-40)

Endothelial dysfunction occurs in many cardiovascular diseases, including hypertension, diabetes mellitus, hyperlipidemia, and atherosclerosis. ${ }^{1-3}$ It is also estimated to occur in a clinically relevant manner in as many as $2.5 \%$ of patients after cardiac surgery, ${ }^{4}$ with electrocardiographic changes occurring in as many as $8 \%$ of patients. ${ }^{5}$ These clinical events are thought to be secondary to altered vasomotor regulation caused by coronary artery and microvascular spasm. This altered response has been implicated as a cause of myocardial ischemia in a number of clinical situations, such as angina, acute coronary syndrome, and vasospasm after coronary artery bypass grafting with cardioplegic cardiopulmonary bypass (CP-CPB). A number of vasoactive substances have

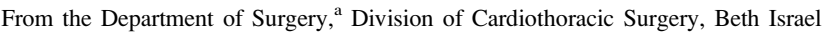
Deaconess Medical Center, Harvard Medical School, Boston, Mass; the School of Veterinary Medicine, ${ }^{\mathrm{b}}$ Federal University of Goias, Goiania, Brazil; and the Department of Surgery, ${ }^{\mathrm{c}}$ Division of Cardiothoracic Surgery, Warren Alpert School of Medicine, Brown University, Providence, RI.

Disclosures: None.

Received for publication Feb 20, 2009; revisions received May 16, 2009; accepted for publication May 31, 2009; available ahead of print of July 27, 2009.

Address for reprints: Frank W. Sellke, MD, Beth Israel Deaconess Medical Center, 330 Brookline Ave. DANA 801, Boston, MA 02215 (E-mail: fsellke@caregroup. harvard.edu)

0022-5223/\$36.00

Copyright (C) 2010 by The American Association for Thoracic Surgery

doi:10.1016/j.jtcvs.2009.05.032
}

been implicated in this process. These include thrombin, ${ }^{5}$ endothelin, ${ }^{6}$ adenosine diphosphate, thromboxane $\mathrm{A}_{2}\left(\mathrm{TXA}_{2}\right){ }^{7}$ acetylcholine, ${ }^{8}$ nitric oxide, ${ }^{9}$ adenosine, ${ }^{10}$ reactive oxygen species (which interfere with endothelium-dependent relaxation), ${ }^{11}$ and serotonin. ${ }^{12}$

Serotonin is a vasoreactive amine with numerous actions affecting the circulation of various organs, and its actions are mediated by multiple receptor subtypes. There are two major serotonin receptor subtypes expressed in heart tissue, 5-HT1B and 5-HT2A, which can have opposing effects on the coronary vasculature. The 5-HT2A receptor often acts as a vasodilator, whereas 5-HT1B acts as a vasoconstrictor. ${ }^{13-15}$ In a recent study, Shimizu and colleagues ${ }^{16}$ infused the 5-HT1B agonist sumatriptan into the coronary arteries of 9 patients, 5 with confirmed variant angina. Sumatriptan elicited coronary artery spasm in all patients with variant angina. Similarly, Dahlof and Mathew ${ }^{17}$ reviewed the literature on reports of cardiovascular complications of patients taking sumatriptan for treatment of migraines. They noted that $3 \%$ to $5 \%$ of patients reported chest tightness or pressure after taking the drug. Although no electrocardiographic or echocardiographic data supported this sensation as being of cardiac origin, they considered the anecdotal data sufficient to recommend caution in using 5-HT1 agonists in patients at high risk for coronary artery disease or vasospasm. In previous studies, we have shown that 


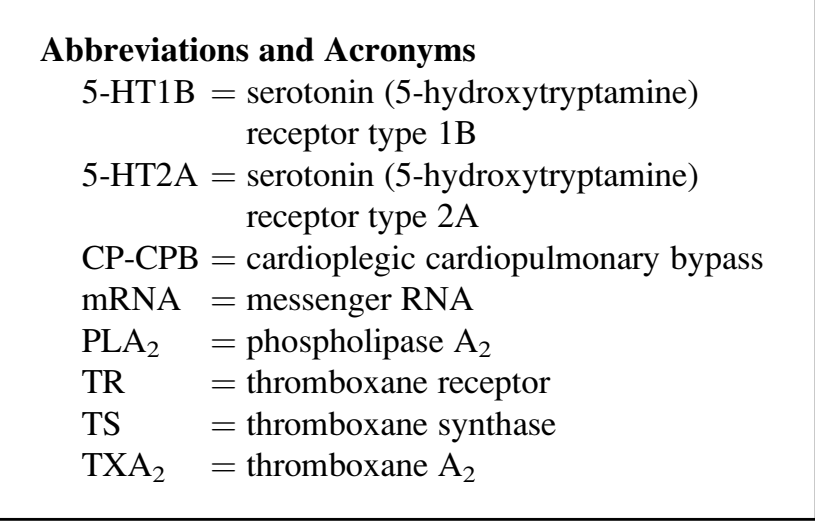

myocardial dysfunction after CP-CPB is associated with increased coronary contraction mediated by serotonin ${ }^{18}$ and with a switch from serotonin-induced coronary vasodilation before CP-CPB to contraction after CP-CPB.

Serotonin has been shown to activate phospholipase $\mathrm{A}_{2}$ $\left(\mathrm{PLA}_{2}\right)$, which is known to release arachidonic acid, the precursor to a number of inflammatory mediators including $\mathrm{TXA}_{2}{ }^{19}$ Activation of $\mathrm{PLA}_{2}$, by serotonin receptors or other receptors, may contribute to vasoconstriction after CP-CPB.

Our hypothesis is that the differential response to serotonin may be caused by a shift in the proportions of receptor subtypes expressed.

Thromboxane synthase (TS) and the thromboxane receptor (TR) have also been implicated in leading to vasoconstriction after CP-CPB, and in conjunction with serotonin may lead to further exacerbation of the vessel contraction. It is clear this is a complex and multifactorial process, and this study was designed specifically to examine changes induced in the serotonin receptor subtypes, TS, TR, phospholipase $\mathrm{C}$ (PLC), and $\mathrm{PLA}_{2}$ by CP-CPB, because these may contribute to a vasoconstrictive local milieu after CP-CPB.

\section{MATERIALS AND METHODS \\ Collection of Tissues}

Right atrial tissues were harvested from patients undergoing coronary artery bypass grafting with CP-CPB. Aspirin was discontinued 24 hours before surgery, but other medications were continued up to the time of
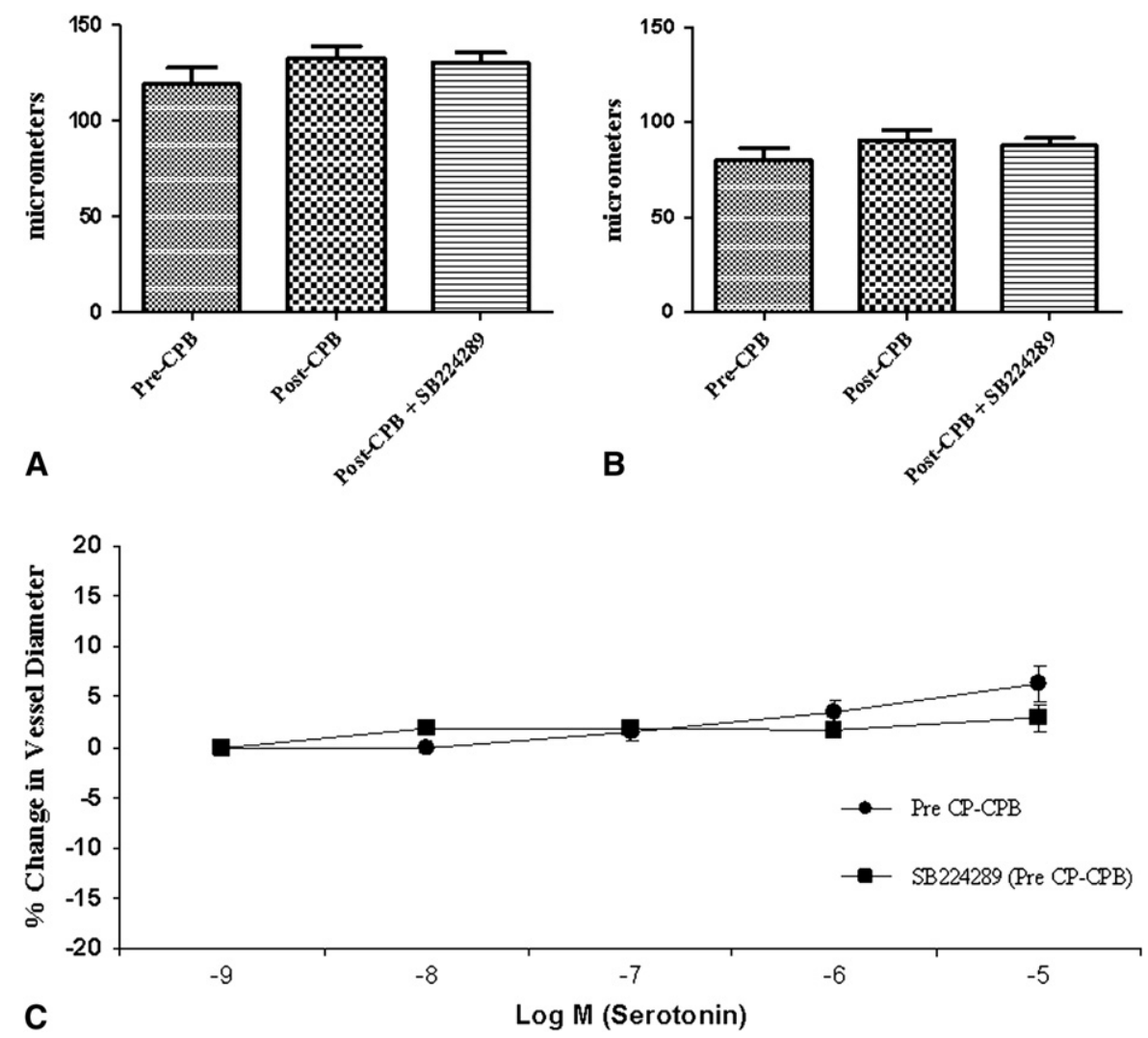

FIGURE 1. Coronary microvascular response to serotonin in vitro. A, Diameter of microvessels before precontraction. There was no difference among groups in baseline vessel diameter $(p=.4)$. B, Diameter of microvessels after precontraction. Vessels were precontracted with U46619, thromboxane $\mathrm{A}_{2}$ analog. There were no differences among groups before addition of serotonin $(\mathrm{p}=.31)$. $\mathrm{C}$, Serotonin responses of vessels harvested before cardiopulmonary bypass with cardioplegic arrest (Pre-CP-CPB) with and without selective serotonin 1B receptor blocker (SB224289). Blocker administered in presence of serotonin to microvessels harvested before cardiopulmonary bypass with cardioplegic arrest resulted in response similar to serotonin alone $(P=.44)$. Pre-CPB, Before cardiopulmonary bypass; Post-CPB, after cardiopulmonary bypass; $P$ ost-CPB $+S B 224289$, after cardiopulmonary bypass with serotonin 1B receptor blocker SB224289. 
operation. Double cannulation sutures were placed in the atrial appendage. The first excised portion of right atrial tissue was harvested after heparinization but before initiation of CP-CPB (before group). The second portion of atrium was harvested after crossclamp removal and termination of CP-CPB but before protamine administration (after group). Cold blood cardioplegia solution was used. Tissues in the before and after groups were immediately frozen in liquid nitrogen after harvest in preparation for molecular studies, placed in cold $\left(5^{\circ} \mathrm{C}-10^{\circ} \mathrm{C}\right) \mathrm{Krebs}$ buffer solution for vascular reactivity studies, or fixed in $10 \%$ formalin overnight and embedded in paraffin for immunohistochemical studies.

The study was approved by the clinical research committee of Beth Israel Deaconess Medical Center. Informed consent was obtained from each patient.

\section{In Vitro Atrial Microvascular Studies}

Coronary microvascular reactivity was examined in the ischemic territory as previously described. ${ }^{20}$ Briefly, coronary arterioles $(70-180 \mu \mathrm{m})$ were dissected with a $40 \times$ microscope. Microvessels were mounted on dual glass micropipettes and examined in a pressurized, isolated microvessel chamber. Relaxation responses of microvessels were examined after development of spontaneous tone with supplemental precontraction by the $\mathrm{TXA}_{2}$ analog U46619. Vascular responses to serotonin $\left(10^{-9}-10^{-4}\right.$ $\mathrm{mol} / \mathrm{L}$ ) alone and in the presence of a specific 5-HT1B receptor antagonist, SB224289 $\left(10^{-6} \mathrm{~mol} / \mathrm{L}\right)$, before and after CP-CPB were examined. Vessel responses to inhibitors of $\mathrm{PLA}_{2}$ (quinacrine, $10^{-6} \mathrm{~mol} / \mathrm{L}$ ) and PLC (U73122, $10^{-6} \mathrm{~mol} / \mathrm{L}$ ) before and after CP-CPB were also examined. All reagents were from Sigma-Aldrich (St Louis, Mo).

\section{Expressions of 5-HT1B and 5-HT2A Messenger RNA}

For 5HT-1B and 5HT-2A messenger RNA (mRNA) studies, semiquantitative reverse transcriptase-polymerase chain reaction was performed. Primers were designed on the basis of published sequences. ${ }^{14}$ The 5HT1A primers of the sense 5'-ACAGAATTCATGGATGTGCTCA GCCCTGGTCA-3' and the antisense $5^{\prime}$-TCTGTCGACTCACTGGCGG CAGAAGTTACACTTAAT- $3^{\prime}$ were used. For 5 -HT2A, the primer of sense $5^{\prime}$-GCGGGTACCATGCAATTAAATGATGACACCAGGCTC-3' and the antisense $5^{\prime}$-TATCTCGAGTCCACAGTTGCCACGGCAACTA$3^{\prime}$ were used. Equal amounts of total RNA were used. For quantification, glyceraldehyde-3-phosphate dehydrogenase was amplified from the same amount of RNA to correct for variation of different samples. The polymerase chain reaction products were loaded in a $1 \%$ agarose gel containing ethidium bromide and scanned and quantified with Image-Quant software (Molecular Dynamics, Sunnyvale, Calif).

\section{Expressions of 5-HT1B, 5-HT2A, TS, and TR Proteins}

Myocardial samples were homogenized in radioimmunoprecipitation assay buffer (Boston Bioproducts, Worcester, Mass) and protein concentration determined by BCA assay (Thermo Fisher Scientific Inc, Waltham, Mass). Total protein ( $40 \mu \mathrm{g} / \mathrm{lane}$ ) was fractionated by $10 \%$ sodium dodecyl sulfate polyacrylamide gel electrophoresis and transferred to a polyvinylidene difluoride membrane (Immobilon-P; Millipore, Bedford, Mass). Equal protein loading was determined by Ponceau staining. The membranes were incubated with either anti-5-HT1B at 1:100 (vol/vol) dilution (BD
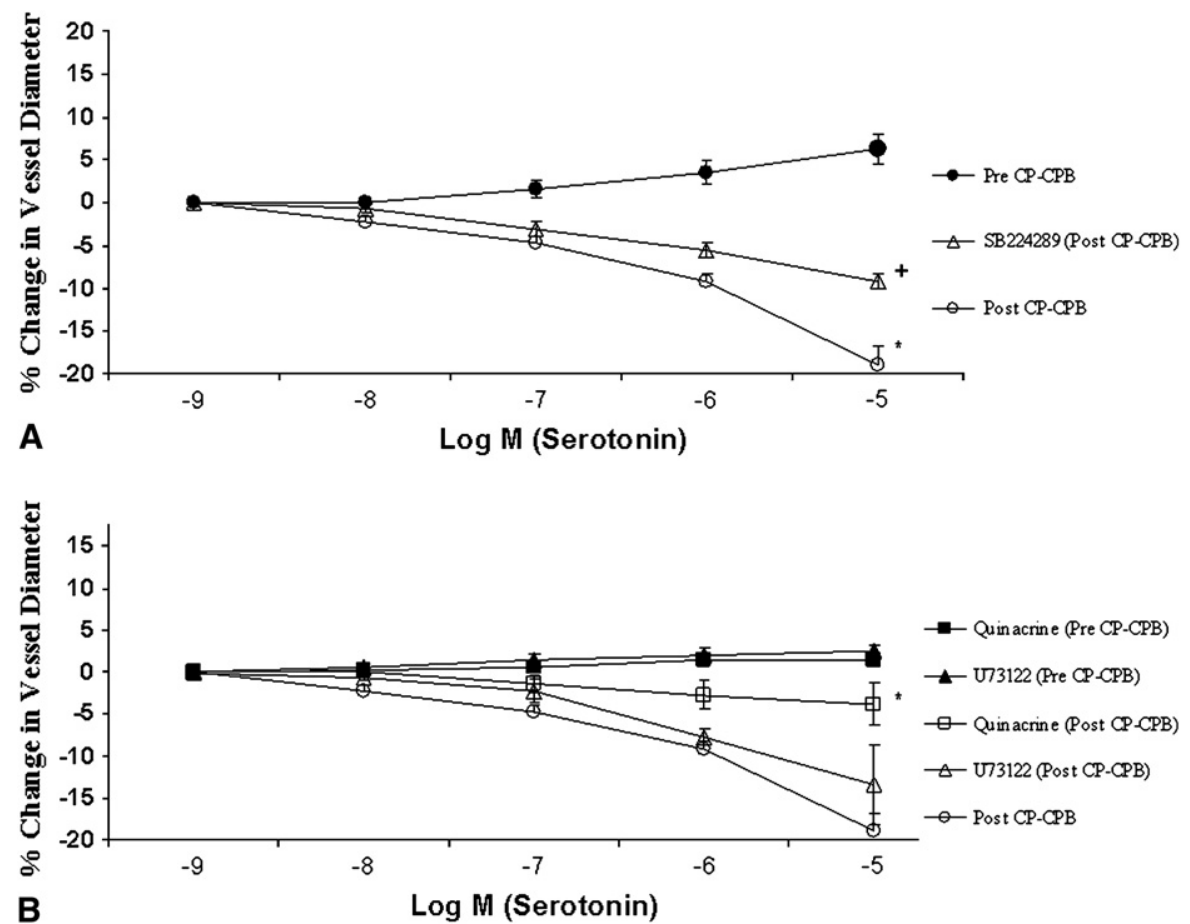

FIGURE 2. Serotonin-induced coronary microvascular response to serotonin receptor 1B inhibitor (SB224289), phospholipase C inhibitor (quinacrine), and phospholipase $\mathrm{A}_{2}$ inhibitor (U73122) in vitro. A, Coronary microvascular response to serotonin demonstrates relaxation response before cardioplegic cardiopulmonary bypass (Pre $C P-C P B$ ). After bypass (Post $C P-C P B$ ), microvessels switched to strong contraction response. After addition of serotonin $1 \mathrm{~B}$ receptor blocker SB224289, postbypass contraction response was significantly diminished. Asterisk indicates difference before and after bypass $P<.001 ;$ plus sign indicates difference after bypass with and without antagonist $P<.001$. B, Microvascular response to serotonin in presence of phospholipase $\mathrm{C}$ inhibitor quinacrine and phospholipase $\mathrm{A}_{2}$ inhibitor $\mathrm{U} 73122$ before cardioplegic cardiopulmonary bypass (quinacrine to serotonin alone $P=.17, \mathrm{U} 73122$ to serotonin alone $P=$.38). After cardioplegic cardiopulmonary bypass, microvessels subjected to quinacrine yielded significant reduction in contractile response relative to response with serotonin alone (asterisk indicates $P<.001$ ). Contractile response when U73122 was applied to microvessels after cardiopulmonary bypass with cardioplegic arrest was not significantly different from serotonin alone $(P=.58)$. 
Biosciences, San Jose, Calif), anti-5-HT2A at 1:100 dilution (BD Biosciences), anti-TXA ${ }_{2}$ synthase at 1:300 dilution (Santa Cruz Biotechnology, Inc, Santa Cruz, Calif), or anti-TXA 2 receptor at 1:100 (Santa Cruz Biotechnology, Inc). After washing, the membranes were incubated in appropriate secondary antibody. Peroxidase activity was visualized with an enhanced chemiluminescence substrate system (Amersham, Fairfield, Conn) and exposure to x-ray film. Densitometry of digitized x-ray films (ScanJet 4c; Hewlett-Packard Company, Palo Alto, Calif) was performed with ImageQuant software (Molecular Dynamics Inc, Sunnyvale, Calif). Data are presented as mean \pm SEM in arbitrary density units.

\section{Immunohistochemical Studies}

Formalin-fixed tissue samples were deparaffinized, rehydrated, and incubated with $3 \%$ hydrogen peroxide. Antibodies against 5-HT1B or 5-HT2A (2 $\mu \mathrm{g} / \mathrm{mL}$; BD Biosciences) were applied to the sections, and isotypematched control antibody (negative control) was applied in the same dilution for 2 hours at room temperature. After a wash in phosphate-buffered saline solution, immunoreactivity was detected with a biotinylated goat anti-mouse secondary antibody and the avidin-biotin-peroxidase complex (Vector Laboratories, Burlingame, Calif). Color was developed with diaminobenzidine substrate $(1 \mathrm{mg} / \mathrm{mL}$ in phosphate buffered saline solution and $0.03 \%$ hydrogen peroxide). Sections were then counterstained with hematoxylin, dehydrated, and mounted. Photomicrographs were taken with a Zeiss Axiolab microscope (Carl Zeiss Inc, Thornwood, NY) equipped with digital camera (Photodoc, Upland, Calif).

\section{Statistics}

Microvascular reactivity data were analyzed with 2-way repeated measures analysis of variance. Densitometry data were analyzed with 1 way analysis of variance (Systat, San Jose, Calif). Data are reported as mean \pm SEM.

\section{RESULTS}

Atrial was obtained from 13 patients. All were male, with an average age of $66.8 \pm 4$ years. Seventy-seven percent of the patients had hypertension, $54 \%$ had hyperlipidemia, and $23 \%$ had diabetes mellitus. Four were smokers at the time of operation. The average preoperative ejection fraction was $46.4 \% \pm 5.8 \%$. Mean cardioplegia time was $58 \pm 7$ minutes, and the mean time from crossclamp removal until second tissue harvest was $10 \pm 3$ minutes. None of the patients in this study had any major clinical adverse events, including overt evidence of myocardial ischemia, unexpected hemodynamic instability, or cardiac depression.

\section{Microvessel Characteristics}

Atrial microvessel internal diameter ranged from 70 to $180 \mu \mathrm{m}$, averaging $106 \pm 4 \mu \mathrm{m}$ before CP-CPB and 123 $\pm 13 \mu \mathrm{m}$ after CP-CPB (Figure 1, $A$ and $B$ ). The vessels before $\mathrm{CP}-\mathrm{CPB}$ demonstrated a relaxation response that was not affected by the presence of the 5-HT1B receptor antagonist SB224289 (Figure 1, C). After CP-CPB, vessels demonstrated a strong contraction response. This contraction response was diminished in the presence of SB224289 (Figure 2, A). Addition of quinacrine, a selective $\mathrm{PLA}_{2}$ inhibitor, had no effect on the microvessels before CP-CPB but significantly inhibited the contraction response after
CP-CPB. Addition of the PLC inhibitor resulted in no change in the contraction response (Figure 2,B).

\section{Serotonin Receptor, TS, and TR Expressions}

Expressions of 5-HT1B and 5-HT2A receptors were analyzed by semiquantitative reverse transcriptase-polymerase chain reaction. The 5-HT1B receptor mRNA expression increased an average of $1.82 \pm 0.34$-fold after CP-CPB (Figure 3, $A$ and $B$ ), whereas the 5-HT2A receptor mRNA expression was unchanged $(P=.509$; not shown).

Western blotting showed that 5-HT1B protein expression was increased $1.35 \pm 0.7$-fold after CP-CPB (Figure 4, $A$ and $B)$, whereas 5-HT2A receptor did not change $(P=$ .951; not shown). Likewise, TR and TS protein levels were unchanged (Figure 4, $A, C$, and $D$ ).

\section{Immunohistochemical Studies}

Immunohistochemical examination demonstrated increased 5-HT1B expression after CP-CPB, whereas 5-HT2A appeared

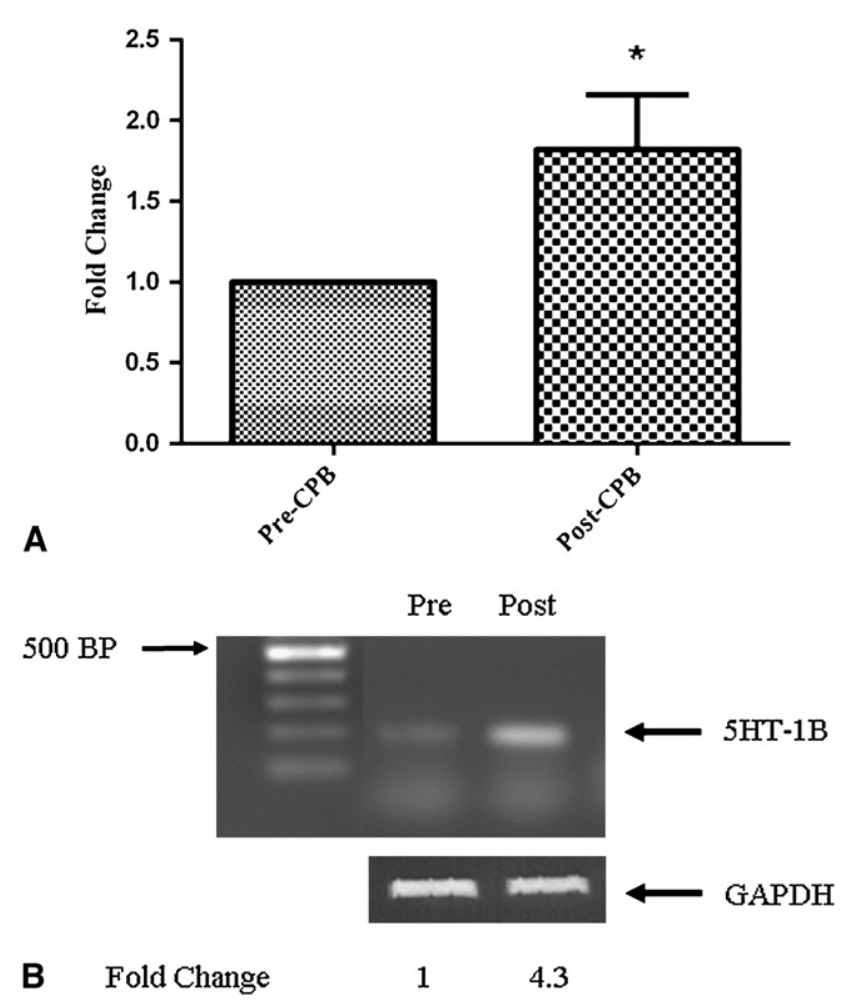

FIGURE 3. Serotonin $1 \mathrm{~B}$ receptor messenger RNA expression by reverse transcriptase-polymerase chain reaction A, Expression of serotonin $1 \mathrm{~B}$ receptor messenger RNA was increased (asterisk indicates $P=.044$ ) after cardiopulmonary bypass (Post-CPB) versus before cardiopulmonary bypass (Pre-CPB). B, Agarose-ethidium bromide gel $(1 \%)$ showing polymerase chain reaction amplification of serotonin $1 \mathrm{~B}$ receptor $(5 H T-1 \mathrm{~B})$ after cardiopulmonary bypass (Post) versus before cardiopulmonary bypass (Pre), normalized to 1 . Glyceraldehyde-3-phosphate dehydrogenase $(G A P D H)$ was used as loading control. Data presented as fold change \pm SEM. BP, Base pairs. 

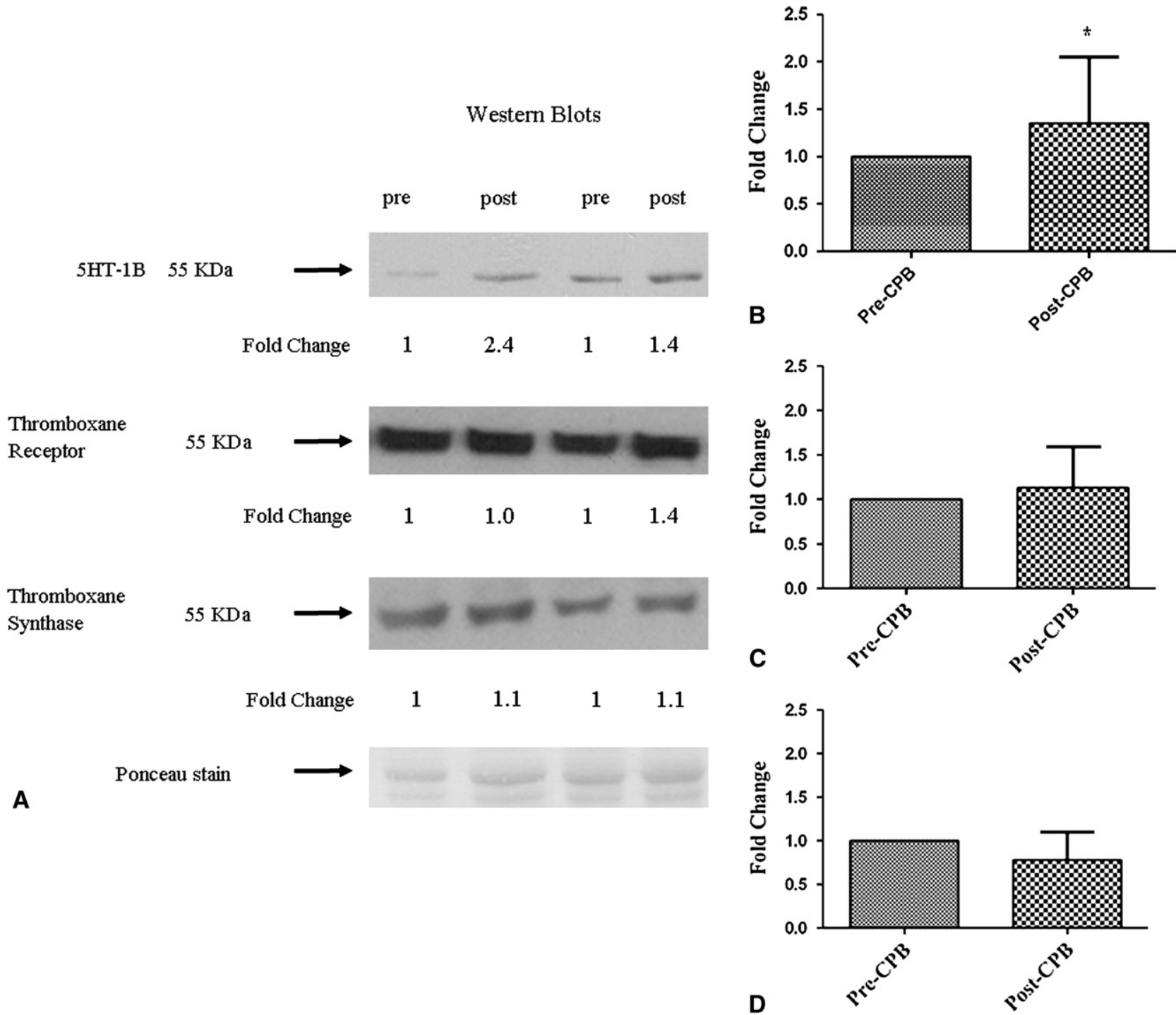

FIGURE 4. Serotonin 1B receptor, thromboxane receptor, and thromboxane synthase protein expressions by western blotting. A, Expression of serotonin 1B receptor protein $(5-H T 1 B)$ was found to increase after cardiopulmonary bypass (post) relative to before cardiopulmonary bypass (pre). Expressions of thromboxane receptor and thromboxane synthase were not significantly changed in myocardial tissue. Ponceau stain is used for loading and transfer monitoring. $\mathrm{B}$, Serotonin $1 \mathrm{~B}$ receptor protein expression after cardiopulmonary bypass (Post-CPB) versus before cardiopulmonary bypass $($ Pre-CPB) normalized to 1 (asterisk indicates $P=.041)$. C, Thromboxane receptor protein expression after cardiopulmonary bypass (Post-CPB) versus before cardiopulmonary bypass (Pre-CPB) normalized to 1 (asterisk indicates $P=.62)$. D, Thromboxane synthase protein expression after cardiopulmonary bypass $(P o s t-C P B)$ versus before cardiopulmonary bypass $($ Pre-CPB) normalized to 1 (asterisk indicates $P=.18$ ). Data presented as fold change \pm SEM.

unchanged (Figure 5, $A$ and $B$ ), particularly in coronary vessels. The 5-HT1B expression was increased in the arterial media smooth muscle. There were no apparent changes in TR (Figure $5, C$ ) or TS (not shown).

\section{DISCUSSION}

In this study, we examined coronary microvascular responses before and after CP-CPB. Atrial microvessels harvested before CP-CPB displayed a small relaxation response to serotonin. In contrast, the coronary vessels isolated after CP-CPB displayed a strong contractile response to serotonin. These findings indicate changes in the vasomotor pathways after surgery, with a possible shift in receptor subtype expression accounting for this functional change. The addition of 5-HT1B blocker significantly diminished the contractile response, suggesting the vasoconstriction after $\mathrm{CP}-\mathrm{CPB}$ is at least in part mediated by 5-HT1B. Addition of a PLA ${ }_{2}$ inhibitor also significantly attenuated the contractile response to serotonin after CP-CPB, but a PLC inhibitor was ineffective. There were no significant differences in the tissue expressions of TR and TS. 


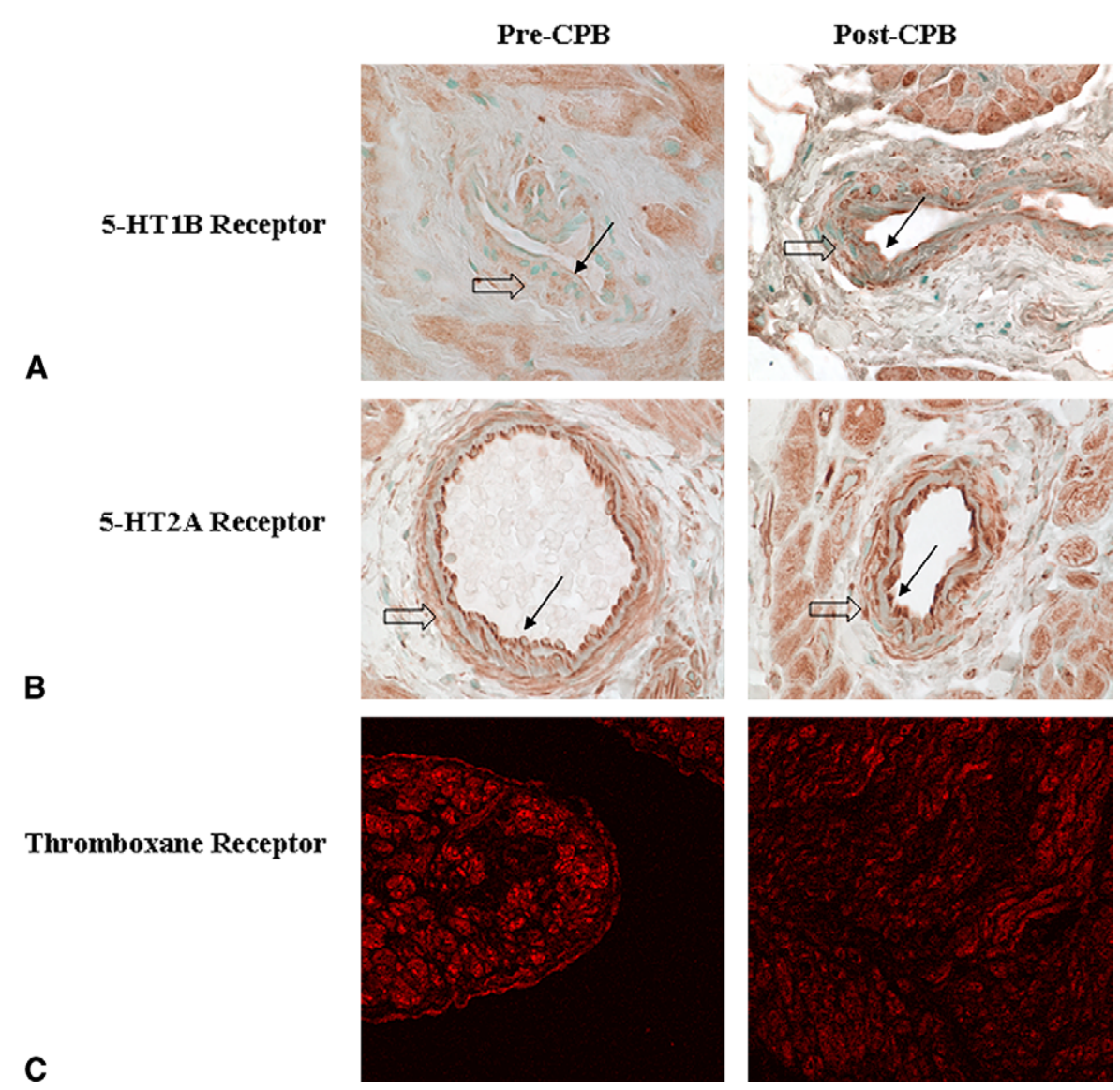

FIGURE 5. Localization of serotonin $1 \mathrm{~B}(5-H T 1 B)$ and serotonin $2 \mathrm{~A}(5-H T 2 A)$ receptors and thromboxane receptor by immunohistochemistry and immunofluorescence, respectively. A, Expression of serotonin 1B receptor is upregulated in vascular smooth muscle cells. B, Expression of serotonin $2 \mathrm{~A}$ receptor is unchanged after cardiopulmonary bypass. C, Expression of thromboxane receptor is unchanged between before and after bypass. Original magnification for immunohistochemistry $400 \times$; original magnification for immunofluorescence $200 \times$. Large open arrow indicates vascular smooth muscle cells; small black arrow indicates endothelium. Pre-CPB, Before cardiopulmonary bypass; Post-CPB, after cardiopulmonary bypass.

Coronary microcirculation provides significant control of myocardial perfusion. ${ }^{21}$ It has been shown that the microvascular response to neurohumoral substances, such as serotonin and norepinephrine, is often different in magnitude or opposite to that observed in large vessels. ${ }^{22,23}$ Thus, the study of microvascular regulation is likely more physiologically relevant than alterations in larger vessels.

To explore further the possibility of altered serotonin receptor expression, we examined the transcriptional and translational products of the two most commonly implicated receptor subtypes. ${ }^{24} \mathrm{We}$ demonstrated upregulation of 5HT1B receptor mRNA and protein expressions by reverse transcriptase-polymerase chain reaction and western blotting. Both 5-HT2A expressions were unchanged. These findings support the concept of a shift in serotonin receptor subtypes in response to $\mathrm{CP}-\mathrm{CPB}$, with 5-HT1B contributing to the change in microvascular response.

An upregulation of the 5-HT1B receptor occurred after surgery. Changes in 5-HT1B receptor expression have been demonstrated in other studies in a similarly brief period. In a study of the cerebral vasculature during ischemia and reperfusion, it was noted that 5-HT1B receptor expression was upregulated in the vascular smooth muscle cells within 60 minutes of the onset of ischemia. ${ }^{25}$ It was hypothesized the expression was controlled by MEK1 activating Erk1 and Erk2, which in turn activated the transcription factor Elk1. In that study, administration of a MEK1 inhibitor diminished the upregulation of 5-HT1B receptor. The dual endothelin 1 receptor antagonist bosentan, used in the treatment of pulmonary hypertension, has also been shown to partially inhibit 5-HT1B receptors and thus may have a role in treatment of vasoconstriction after CP-CPB through antagonist effects on serotonin receptors as well as endothelin. ${ }^{6,26}$

Coronary vasoconstriction has been implicated in myocardial ischemia in a number of clinical situations, including stable and variant angina, acute coronary syndrome, and cardiac surgery. ${ }^{27,28}$ Other studies have indicated that serotonin may contribute to postischemic coronary vascular constriction. ${ }^{8,11,13,14,18}$ It has been postulated that atherosclerosis 

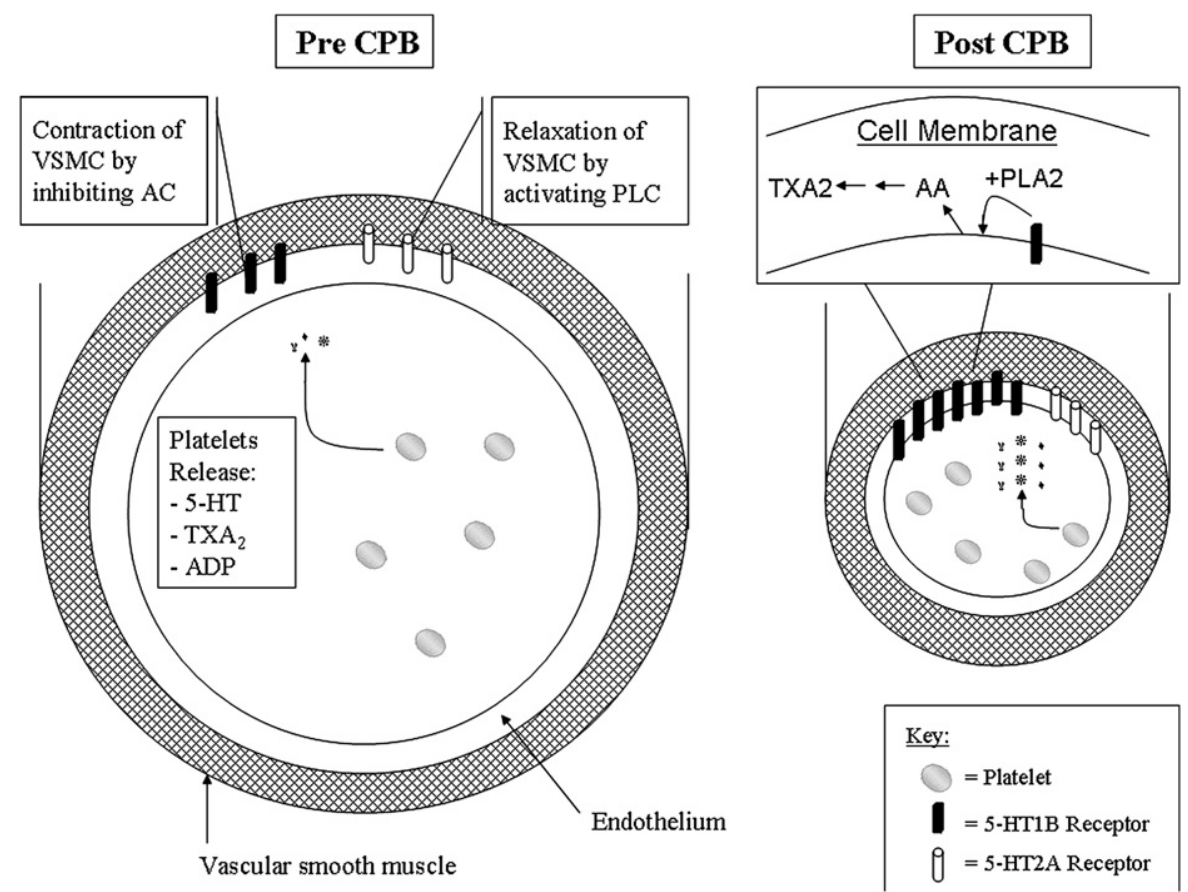

FIGURE 6. Summary of serotonin $(5-H T)$ receptor expression before (Pre $C P B)$ and after (Post $C P B)$ cardiopulmonary bypass. Expression of serotonin $1 \mathrm{~B}$ $(5-H T 1 B)$ receptor is significantly increased after bypass and associated with vasoconstriction, whereas expression of serotonin $2 \mathrm{~A}(5-H T 2 A)$ receptor is unchanged after bypass. Serotonin, thromboxane $\mathrm{A}_{2}\left(T X A_{2}\right)$, adenosine diphosphate $(A D P)$, and other mediators are released from platelets. Platelets are activated after bypass and degranulate, releasing many substances. Endothelium also produces serotonin. Serotonin $1 \mathrm{~B}$ receptors are negatively coupled to adenylyl cyclase $(A C)$, and serotonin $2 \mathrm{~A}$ receptors are positively coupled to phospholipase $\mathrm{C}(P L C)$. Serotonin activates phospholipase $\mathrm{A}_{2}(P L A 2)$ and may lead to further increases in thromboxane $\mathrm{A}_{2}$. All signals influence vascular smooth muscle cells (VSMC) to respond. AA, Arachidonic acid.

may cause a shift in serotonin receptor subtypes in vascular smooth muscle cells by increased receptor-mediated calcium ion mobilization. ${ }^{24}$ Serotonin receptor subtypes have various, and at times opposing, effects on different vascular beds in different species. ${ }^{7,13,29}$ Both 5-HT1B and 5-HT2A are expressed on the vascular smooth muscle cells, but they mediate their responses through different mechanisms. The 5-HT1B receptors work through $\mathrm{PLA}_{2}$ and adenylyl cyclase; in contrast 5-HT2A receptors are positively coupled to PLC. ${ }^{29,30}$ Although our evidence strongly supports increased $\mathrm{PLA}_{2}$-dependent 5-HT1B signaling, we can not definitively rule out that changes in microvessel reactivity might be due to alternative changes in second messengers or other unaccounted for receptor subtypes.

TS and the TR have also been implicated in causing vasoconstriction after CP-CPB. We have previously shown that cyclooxygenase 2 expression is increased after cardiac operations, and the presence of a cyclooxygenase 2 inhibitor or a TS inhibitor markedly diminishes the contractile response to serotonin in this setting. ${ }^{12}$ From that study, it appears that serotonin elicits the synthesis and release of $\mathrm{TXA}_{2}$. This may be mediated by activation of PLA $\mathrm{P}_{2}$, which releases arachidonic acid and leads to production of, among other products, $\mathrm{TXA}_{2} \cdot{ }^{31-33}$ In this study, we found no significant differences in TS and TR expression, although activity was not measured. The improvement by the $\mathrm{PLA}_{2}$ inhibitor in contraction after CP-CPB may be secondary to production of less $\mathrm{TXA}_{2}$. Studies measuring levels of TXA2 locally in the presence of a $\mathrm{PLA}_{2}$ inhibitor would be needed to support this.

In addition, the roles of platelets and other circulating cells in this process are not accounted for, and they have been shown to be critical. ${ }^{34}$ It is possible that the primary source of serotonin in the post-cardiac surgery setting is from activated platelets. In a study characterizing the expression of TS, it was found to be most abundant in circulating cells, being present to a lesser degree in spleen, liver, and lung, and essentially undetectable in heart tissue. ${ }^{35} \mathrm{Al}-$ though there did not appear to be any changes in TS and TR expressions in the atrial microcirculation, circulating blood components, mostly platelets, may be delivering higher concentrations of thromboxane and serotonin to the vessel and thus effecting a greater response.

In this study, we found an approximately $50 \%$ reduction in the vasoconstrictive response with a specific 5-HT1B receptor blocker and $84 \%$ reduction with an inhibitor of the second messenger PLA $\mathrm{PL}_{2}$, both of which should result in significant hemodynamic improvement. This also indicates, however, that there are other factors contributing to the vasoconstriction. Studies are currently underway to characterize other mediators of vasomotor dysfunction after CPCPB. 


\section{LIMITATIONS}

This study has shown the potential role in coronary vasospasm after cardiac surgery of changes in serotonin receptor expression. A limitation of this study, however, is the relatively small sample size. There were multiple and varying risk factors in each patient, all of which could have had an impact on the results. It is possible that there are differences depending on the presence of diabetes, hypercholesterolemia, and other coexisting conditions, or certain medications may have effects. Future studies with larger numbers of patients could be undertaken to elucidate further how specific variables, such as comorbidities and medications (eg, $\beta$-blockers, amiodarone, angiotensin-converting enzyme inhibitors, and insulin) contribute to the observed process. Future studies will also further examine the second messengers involved with the 5-HT1B receptor, because these may be different before and after $\mathrm{CP}$ $\mathrm{CPB}$, leading to the divergent vasomotor responses. In addition, right atrial tissues were examined as a surrogate for ventricular myocardium. We have already shown, however, that human atrial myocardial microvessels responses are similar to those observed in the ventricular microcirculation.

\section{Clinical Implications}

The contraction response demonstrated in this experiment has been implicated as a cause of myocardial ischemia in a number of clinical situations, such as angina, acute coronary syndrome, and vasospasm after cardiac surgery. It is clearly a complex and multifactorial process mediated by a number of pathways. Antagonizing the increased vasoconstrictive 5-HT1B receptor along with other components in the signaling pathways may allow clinicians to alleviate myocardial ischemia in the postsurgical setting.

\section{References}

1. Sellke FW, Li J, Stamler A, Lopez JJ, Thomas KA, Simons M. Angiogenesis induced by acidic fibroblast growth factor as an alternative method of revascularization for chronic myocardial ischemia. Surgery. 1996;120:182-8.

2. Luscher TF, Tanner FC, Tschudi MR, Noll G. Endothelial dysfunction in coronary artery disease. Annu Rev Med. 1993;44:395-418.

3. Perrault LP, Mahlberg F, Breugnot C, Bidouard JP, Villeneuve N, Vilaine JP, et al. Hypercholesterolemia increases coronary endothelial dysfunction, lipid content, and accelerated atherosclerosis after heart transplantation. Arterioscler Thromb Vasc Biol. 2000;20:728-36.

4. Buxton AE, Hirshfeld JW Jr, Untereker WJ, Goldberg S, Harken AH, Stephenson LW, et al. Perioperative coronary arterial spasm: long-term followup. Am J Cardiol. 1982;50:444-51.

5. Skarvan K, Graedel E, Hasse J, Stulz P, Pfisterer M. Coronary artery spasms after coronary artery bypass surgery. Anesthesiology. 1984;61:323-7.

6. Vane JR, Anggard EE, Botting RM. Regulatory functions of the vascular endothelium. N Engl J Med. 1990;323:27-36.

7. Mohammad-Zadeh LF, Moses L, Gwaltney-Brant SM. Serotonin: a review. J Vet Pharmacol Ther. 2008;31:187-99.

8. Sun H, Mohri M, Shimokawa H, Usui M, Urakami L, Takeshita A. Coronary microvascular spasm causes myocardial ischemia in patients with vasospastic angina. J Am Coll Cardiol. 2002;39:847-51.

9. Stowe DF, Ebert TJ. Neural and endothelial control of the peripheral circulationimplications for anesthesia: part II, endothelium-mediated effects in the normal and diseased circulation. J Cardiothorac Vasc Anesth. 1996;10:159-71.

10. Sellke FW, Boyle EM Jr, Verrier ED. Endothelial cell injury in cardiovascular surgery: the pathophysiology of vasomotor dysfunction. Ann Thorac Surg. 1996;62:1222-8.
11. Sellke FW, Friedman M, Dai HB, Shafique T, Schoen FJ, Weintraub RM, et al. Mechanisms causing coronary microvascular dysfunction following crystalloid cardioplegia and reperfusion. Cardiovasc Res. 1993;27:1925-32.

12. Metais C, Bianchi C, Li J, Simons M, Sellke FW. Serotonin-induced human coronary microvascular contraction during acute myocardial ischemia is blocked by COX-2 inhibition. Basic Res Cardiol. 2001;96:59-67.

13. Cote F, Fligny C, Fromes Y, Mallet J, Vodjdani G. Recent advances in understanding serotonin regulation of cardiovascular function. Trends Mol Med. 2004; $10: 232-8$.

14. Ishida T, Hirata K, Sakoda T, Kawashima S, Akita H, Yokoyama M. Identification of mRNA for 5-HT1 and 5-HT2 receptor subtypes in human coronary arteries. Cardiovasc Res. 1999;41:267-74.

15. Chester AH, Martin GR, Bodelsson M, Arneklo-Nobin B, Tadjkarimi S, Tornebrandt $\mathrm{K}$, et al. 5-Hydroxytryptamine receptor profile in healthy and diseased human epicardial coronary arteries. Cardiovasc Res. 1990;24:932-7.

16. Shimizu M, Hata K, Takaoka H, Kanazawa K, Shinke T, Matsumoto H, et al. Sumatriptan provokes coronary artery spasm in patients with variant angina: possible involvement of serotonin 1B receptor. Int J Cardiol. 2007;114:188-94.

17. Dahlof CG, Mathew N. Cardiovascular safety of 5HT1B/1D agonists-is there a cause for concern? Cephalalgia. 1998;18:539-45.

18. Metais C, Li J, Simons M, Sellke FW. Serotonin-induced coronary contraction increases after blood cardioplegia-reperfusion: role of COX-2 expression. Circulation. 1999;100(19 Suppl):II328-34.

19. Berg KA, Clarke WP. Regulation of 5-HT(1A) and 5-HT(1B) receptor systems by phospholipid signaling cascades. Brain Res Bull. 2001;56:471-7.

20. Sodha NR, Clements RT, Feng J, Liu Y, Bianchi C, Horvath EM, et al. The effects of therapeutic sulfide on myocardial apoptosis in response to ischemia-reperfusion injury. Eur J Cardiothorac Surg. 2008;33:906-13.

21. Chilian WM, Layne SM, Klausner EC, Eastham CL, Marcus ML. Redistribution of coronary microvascular resistance produced by dipyridamole. Am J Physiol. 1989;256(2 Pt 2):H383-90.

22. Lamping KG, Kanatsuka H, Eastham CL, Chilian WM, Marcus ML. Nonuniform vasomotor responses of the coronary microcirculation to serotonin and vasopressin. Circ Res. 1989;65:343-51.

23. Chilian WM, Layne SM, Eastham CL, Marcus ML. Heterogeneous microvascular coronary alpha-adrenergic vasoconstriction. Circ Res. 1989;64:376-88.

24. Ishida T, Kawashima S, Hirata K, Sakoda T, Shimokawa Y, Miwa Y, et al. Serotonin-induced hypercontraction through 5-hydroxytryptamine $1 \mathrm{~B}$ receptors in atherosclerotic rabbit coronary arteries. Circulation. 2001;103:1289-95.

25. Maddahi A, Edvinsson L. Enhanced expressions of microvascular smooth muscle receptors after focal cerebral ischemia occur via the MAPK MEK/ERK pathway. BMC Neurosci. 2008;9:85.

26. Rondelet B, Van Beneden R, Kerbaul F, Motte S, Fesler P, McEntee K, et al. Expression of the serotonin $1 \mathrm{~b}$ receptor in experimental pulmonary hypertension. Eur Respir J. 2003;22:408-12.

27. Maseri A, L'Abbate A, Baroldi G, Chierchia S, Marzilli M, Ballestra AM, et al. Coronary vasospasm as a possible cause of myocardial infarction. A conclusion derived from the study of "preinfarction" angina. N Engl J Med. 1978;299:1271-7.

28. Willerson JT, Golino P, Eidt J, Campbell WB, Buja LM. Specific platelet mediators and unstable coronary artery lesions. Experimental evidence and potential clinical implications. Circulation. 1989;80:198-205.

29. Villalón CM, Centurión D. Cardiovascular responses produced by 5-hydroxytriptamine: a pharmacological update on the receptors/mechanisms involved and therapeutic implications. Naunyn Schmiedebergs Arch Pharmacol. 2007;376:45-63.

30. Xu J, Jian B, Chu R, Lu Z, Li Q, Dunlop J, et al. Serotonin mechanisms in heart valve disease II: the 5-HT2 receptor and its signaling pathway in aortic valve interstitial cells. Am J Pathol. 2002;161:2209-18.

31. Hassantash SA, Omrani GR, Givtaj N, Afrakhteh M. Pharmacological prevention of the deleterious effects of cardiopulmonary bypass. Asian Cardiovasc Thorac Ann. 2007; 15:218-24.

32. Heying R, van Oeveren W, Wilhelm S, Schumacher K, Grabitz RG, Messmer BJ, et al. Children undergoing cardiac surgery for complex cardiac defects show imbalance between pro- and anti-thrombotic activity. Crit Care. 2006;10:R165.

33. Huang H, Yao T, Wang W, Zhu D, Zhang W, Chen H, et al. Continuous ultrafiltration attenuates the pulmonary injury that follows open heart surgery with cardiopulmonary bypass. Ann Thorac Surg. 2003;76:136-40.

34. Shen RF, Tai HH. Thromboxanes: synthase and receptors. J Biomed Sci. 1998;5: 153-72.

35. Miyata A, Yokoyama C, Ihara H, Bandoh S, Takeda O, Takahashi E, et al. Characterization of the human gene (TBXAS1) encoding thromboxane synthase. Eur J Biochem. 1994;224:273-9. 